stable solution of the protochloride is obtained; but when water is added to the solution hydrogen is evolved and gallium perchloride is produced.

Herr Schwarz describes (in Berichte der Deut. Chem. Ges., xv. 2505) three lecture experiments illustrative of the action of zinc on sulphur : 2 parts of fine zinc powder are carefully mixed with I part of flowers of sulphur, and the mixture is ignited by an ordinary match ; combination occurs with evolution of much light. Vapour of carbon divulphide is passed over zinc powder, which is gently heated in a piece of glass tubing ; zinc sulphide is produced, and a considerable quantity of carbon i; separated. Sulphuretted hydrogen is passed through carbon disulphide, and the mixed gases are then conducted over hot zinc powder; zinc sulphide is produced, and a gas, which is passed through potash and collected in a small gas-holder; this gas burns with a slightly luminous flame, and explodes when mixed with air; it is marsh gas.

Nilson has prepared the rare metal thorium in considerable quantity, and determined its atomic weight to be $23^{\circ} 35$, specific gravity about II, and atomic volume about 2I (Berichte, xv. 25I9).

\section{MIKLUKHO-MACLAY ON NEW GUINEA}

$A$ MONG the queries that were submitted to $M$. MilukhoMaclay before his departure fron Europe, was one of Karl von Baer, who advised the traveller to visit the Philippine Islands, and to bring home several skulls of the natives, in order to ascertain whether the primitive inhabitants of these islands are brachiocephalic, or not. During a five days' stay of the clipper Izumrud at Manila, M. Maclay visited the Mariveles mountains, and discovered there Negritos who lived in their pondos, or small huts made out of palm-tree leaves. Numerous measurements (favoured by the custom of the men shaving the back of the head) proved that they really are brachiocephalic, the index being no less than $87^{\circ} 5$ to 90 Their size is altogether small; one wo nan, mother of two children, measured only $\mathbf{I}^{\circ} 3^{\circ}$ metre. Their faces proved to be very much like those of the Papuans of New Guinea, while their customs are much akin to those of the inhabitants of many Melanesian islands. For instance, when M. Maclay threw some remains of food in the fire, the Negritos immediately extinguished it, and asked him not to do so again. The same prejudice exists with regard to spitting in the fire (a very widely-spread prejudice, we may observe, as it exists also in Russia and Siberia). Another interesting custom of the Negritos is that everybody, before eating, must loudly shout out several times, an invitation to partake of his food, to all those who may be in proximity. This custom is very rigidly observed, and those who do not comply with it are punished, even by death.

In August, 1874, M. Miklukho-Maclay undertook a journey into the interior of the Malay peninsula, in order to settle the question as to the race of its inhabitants-the Orang-Sokays and the Orang-Semongs-about which question there existed a controversy between Messrs. Logan, Newbold, Crawford, and Waitz. M. Maclay went, therefore, from Singapore to Johore. The Maharajah of Johore received him very kindly, and gave him the necessary men for the journey, as well as orders to his subjects to help him in every way during his journey. In exchange, M. Maclay was bound to prepare a map of the dominions of the Maharajah. The Russian traveller crossed the Johore country twice-from west to east and from north to south. The journey was very difficult, on account of the rainy season; the rivers and streams had inundated the country, even the woods, and the party had to walk in water that reached to the knees, and often to the breasts of the oxen. For seventeen consecutive day; they were quite wet, as well as their baggage. Reaching thus the mouth of the Moar river, M. Maclay journeyed up this river in a flat boat, passing by Malayan villages, reached its confluence with the Pallon, and went up the last river. At its sources he discovered in the woods the first hats of the so-called "orang-utangs." This name is given by the Malayans, not to the ape, Pithecus satyrus-they never call apes by the name of "orang," but to "forest-men." "Orang" signifies "man," and "utang" a forest. Therefore the Malay. ans say orang-bukit (men of the hills), orang-ulu (men at the source of a river), orang-dalah, orang-laut (men of the interior of the sea-shore), and so on. However, the name orang-utang

\footnotetext{
Continued from p. $13^{8}$
}

could be applied also to a Malay who stays in the woods, but still it is used to desi gnate a tribe of Malays crossed in various degrees with Papuans, as also with Melanesians.

Though the different tribes M. Maclay met with during his journeys in Johore differ from one another, still none of them are Melanesians. They forget their primitive language, and adopt that of the Malays. M. Maclay presumes that formerly they had several languages, and were divided into several tribes; some difference still remains in their customs. They are at a very low stage of human culture. They wander in the woods, and only occasionally come to stay in their mi ierable huts. The Malays distinguish two different tribes of orang-outangs: the orang-outang-dina (or tame, who are in intercourse with them), and the orang-outang-liar, quite nomadic. These last use a weapon, sumpitan, which deserves to be mentioned. It consists of a hollow bamboo cylinder, two metres long and two or three centimetres wide, through which they blow against their enemies very light poisoned arrows, as large as knitting-needles. The end of these arrows breaks, and remains in the wound. The Malays say that the slightest scratch of such an arrow kills a man in ten or fifteen minutes. M. Maclay purchased quantities of their poison, which proved always to be made of a condensed infusion of the bark of the Javan tree, Antiaris toxicoria, or Upas, to which different tribes add other poisons, such as the poison of snakes, of poisonous kinds of strychnis, \&c. A small prick of a poisoned arrow kills a dog or a cat, the death being accompanied by tetanus or not, according to the secondary poisons added to the chief one. The Orang-outangs are rapidly disappearing since they were driven by Chinese and Malayans from the sea-shore $t ?$ the woods of the interior. Besides, the Chinese and Malays purchase their best-looking and healthier girls, leaving them the feeblest, who leave but a weak progeny. The children from the Malays and Orang-outang girls are far more like the former than the latter.

After having crossed the Johore country from the mouth of the Moar River to the entrance of the Indan into the Chinese Sea, that is, from west to east, M. Maclay crossed the same country from north to south, that is from the Indan to the Selat-tebran Strait, which separates Singapore Island from the mainland. He contracted, of course, a strong fever during this journey, fifty days long, and went to Bangkok. There he happened to receive from the King of Siam a letter to his vassals of the Malay peninsula, enjoining them to help M. Maclay during his further travels on the peninsula. Provided with this recommendation, the Russian traveller undertook a most adventurous journey, namely, to walk from Johore to Siam. It was considered by all his acquaintances as quite imposible, but he accomplished it, as the small rulers of the southern part of the Malay peninsula did not venture to stop him on his way, and preferred, each of them, to despatch him to the next ruler. In this way M. Maclay rexched Siam, after a journey that lasted for 176 days.

In the mountains at the sources of the Pakkan River, M. Maclay finally met with undoubtedly pure Melanesian;, Orang. Sakays, and made on them a few anthropological measurements. They differ as much from the Malayans, as the Malayans differ from the Papuans, and are like the Neyritos of Luzon. The height of the men varies between $I^{\circ} 46$ and $I^{\circ} 62$ metres, and that of the women from $\mathrm{I} 35$ to $1 \cdot 48$; the skull is nearly brachiocephalic, that is, the widest is between 74 to 82 for men, 75 to 84 for women, and 74 to $8 \mathrm{I}$ for children. The diameter of the curls of the hairs is the same as with the Papuans, that is, from 2 to 4 millimetres. The colour of skin is between the numbers 28 to 42 , and 2 I to 46 of the table of Broca. The plica semilunaris, or the so-called palabra tertia, is more deve. loped than with other races; its width re iches sometimes 5 and 5.5 millimetres, instead of the I' 5 to 2 millimetres of the Caucasian race. Finally the Orang-sakays have also a fold of the skin at the interior corner of the eye which i; known, when pathologically developed, under the name of Epicanthus. Like the Orang-utangs they are disappearing; they nomadize in forests, stoppiny at a few places to mass collections of camphor and caoutchouc tree, of rotang and elephant bone, "hich they exchange with Malays for tobacco, salt, iron knives, and various rugs which they use fur their dress. The dress of the men consists of a girdle, a part of which covers the perinacum: the women have alsu a girdle of rotang, to which two rugs are adjusted. The women are tattooed by lines and round spots. The Orang-sakays, like other Melanesians, put in the partition of the nose the hayanmsh, that is, a long stick of bamboo, or a spike of the Hystria. 
The Orang-sakays are very kind to their women and daughter:, who can even inherit the title of Pateu. Their wedding customs contain survival of the cuttom of stealing brides. On a day agreed to before, the bride, in presence of ber parents and friends, runs away to the forests, and the bridegroom, who follows her after some time, must find her during a fixed lapse of time. If she does not wish to marry him she can always conceal herself in the wo ods so as not to be found. They have maintained also the communal marriage, that is, the wife passes from one man to another for a certain time. They are much afraid of death, and if a member of the community becomes seriously ill, they abandon him in the forest with a supply of food, and leave their buts for ever.

In his fourth lecture, M. Miklukho-Maclay gave an account of his cruise among the i-lands of the Malayan Archipelago, at the islands of Micronesia and Melanesia, as well as of his work in Australia. The anthropological researches in the Malayan archipelago were far more successful than in Melanesia or New Guinea. He had no longer to deal with wild tribes, and the schools, hospitals, and prisons maintained by the Dutch on

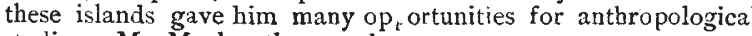
studies. M. Maclay thus made very numerous measurements and photographs of Malayans, which will afford the necessary materials for comparing them with other allied races.

In 1876 , when going for a second time to the Maclay coast of New Guinea, the indefatigable traveller had an opportunity of visiting the islands of Western Micronesia. He found there that the Micronesian race is very nearly akin to the Polynesian; but still, be thinks it is most probable that it contains a mixture of Melanesian blood, which appears, especially in the more curly hair ; in several instances (on the Pelan Islands), the hairs were purely Melanesian, and the darkness of the skin and several distinctive features of the skull showed unmistakable traces of mixture with Melanesians. On the Lub, or Hermit Islands, M. Maclay found a mixture of Melanesians with Micronesians, and on the next group of islands, Escheker, or Eschikie, he discovered the true border-line of the straight-haired Micronesian race. The most important results of this jurney were published in the Sitzungsberichte der Berlinır Gesellschaft für Anthropologie, \&c., meeting of March 3,1878 .

In 1879 M. Maclay left Sydney on board an American schooner for a cruise among the islands of Melanesia. He visited New Caledonia, and journeyed in the interior of it, the Loyalty Islands, and many islands of the New Hebrides, making everywhere anthropological measurements and drawings. Many inhabitants of the New Hebrides proved to be brachiocephalic. Thence be proceeded to the Santa Cruz Islands (where Commodore Goodenough, several sailors, and Bishop Paterson were killed by poisoned arrows), and made measurements of those natives who came on board the schooner. Reaching then the Admiralty Islands, he stayed there for two months, and was enabled to complete to a great extent the observations of the Challenger expedition. Visiting further the Lub or Hermit islands, which are said to have been peopled by a few natives landed in a canoe from the Admiralty Islands, and where the Melanesians are continually crossed with Micronesians, as the inhabitants bring every year slaves and women from the Ninigo group-M. Maclay proceeded to the Trobrian group of islands which are very rarely $v$ sited by Europeans, and thence to the Solomon and the Luisiadea Islands. The journey lasted for 409 days, out of which 237 were spent on shore. The results were as numerous as important, the chief of them being that brachiocephaly is far more usual in Melanesia than it was before ; indexes measuring $8 \mathrm{r}$, and even 85 , being not rare. Further results of this journey were published in the Izvestia of the Russian Geographical Society for 188r, and in a letter to Prof. Virchow, which appeared in the Sitzungsberichte of the Berlin Society of Anthropology.

M. Miklukho-Maclay concluded his journey by landing at Somerset, on the northern extremity of Australia, and at several places of the eastern coast, in order to make acquaintance with the black Australian race. It is known that several opinions are current as to the origin of this race. Some anthropologists consider them as Papuans, while others consider them as Polynesians, and Prof. Huxley has made of them an independent race of Astraloids. As far as M. Maclay's observations go, he is inclined to consider them, like Huxley, as a race sui generis. But he intends to return again to Australia in order further to study this question.

When staying at Brisbane, M. Maclay undertook an excursion into the interior of the country to see if there really exists an "unhaired" race, of which he was told in Europe. Close by Saint George's Town, on the Ballon River, he discovered a few members of one family who really were representatives of the Atrychia universalis; they had only a dozen bairs on their eyelids, and said that they were already a third generation of unhaired people. More details of this occurrence of atrychia, together with observations on inherited hypertrichosis (hairs coverin ? all the body and face) were given by M. Maclay in a letter to Prof. Virchow which appeared in the Verhandlungen of the Berlin Anthropological Society for $188 \mathrm{r}$, as well as several other papers on Australians ("Ueber die Mika Operation in Central Australien ; Langbeinigkeit der australischen Franen," \&c.).

At Brisbane M. Maclay had at his disposal very rich anthropological material for the study of the comparative anatomy of the brain of the Australian, Melanesian, Malayan, and Mongolian races, as the authorities had given him all facilities for having fresh brains of representatives of all these races who died in the hospitals of the port, or were executed. The Survey Office of Brisbane offered him the use of its excellent photographs, which rendered him very great services. This rich material, left mostly at Sydney, has $n$ t t yet been worked out by M. Maclay; but he can already state that the brains of different races afford substantial differences in the development of the corpus callosum, the pons varolii, and the cerebellum, as well as in the relative development of nerves and in the grouping of the sinuosities of the great brain.

Further interesting studies in comparative anatomy were made by M. Maclay on the brains of Marsupials, as well as of the Ornithorhynchus, the Echidna, and others. The chief occupation of M. Maclay in Australia being thus comparative anatomy, he proposed to the Linnean Society of New South Wales to open a biological station where everybcdy could "undisturbed and undisturbing" carry on biological and anatomical studies. The success which has met his proposal our readers already know of. The recently-founded "Australian Biological Association" will take care of the new station.

The Geographical Society not having at its disposal the necessary sums for publishing the scientific work which $M$. Maclay proposes to publish, the Emperor has allowed the sum of $2200 l$. for covering the expenses of the publication.

\section{THE RECENT AND COMING TOTAL SOLAR ECLIPSES ${ }^{\mathrm{I}}$}

THE following note has been drawn up in anticipation of the detailed accoun's of the work done by me in Egypt on the eclipsed sun of $\mathrm{I} 882$, May $\mathrm{I} 7$, which $\mathrm{I}$ am reparing to lay before the Royal Society, because as the next total eclipse occurs next May, there is no time to be lost if any attempt is to be made to secure observations, and I am of opinion that such observations are most important.

I have prefaced the statement of the work done by a reference to the considerations which led me to undertake it, and I have added a scheme of observations which, in the present state of our knowledge is, I think, most likely to produce results of value.

I. In order to understand the recent change of front in solar research which has followed the introduction of the view of the possible dissociation of elementary bodies at solar temperatures, and suggested the later laboratory, and especially the later eclipse observations with which we are now chiefly concerned, we must first consider what facts we may expect on the two hypotheses. In this way we can see which hypothesis fits the facts best, an 1 whether there are any inquiries possible during eclipses of a nature to throw light on the question.

2. On the old hypothesis the construction of the solar atmosphere was imaged as follows :-

(I.) We have terrestrial elements in the sun's atmosphere.

(2.) They thin out in the order of vapour den ity, all being represented in the lower strata, since the solar atmosphere at the lower levels is incompetent to dissociate them.

(3.) In the lower strata we have especially those of higher atomic weight, all together forming a so-called "reversing layer" by which chiefly the Fraunhofer spectrum is produced.

3. The new hypothesis necessitates a radical change in the above views. According to it the three main statements made in paragraph 2 require to be changed as follows :-

I Paper read at the Royal Society, Nov. 23, by J. Norman Lockyer,
F.R S 